\title{
https://doi.org/10.46813/2022-137-111 \\ SYNTHESIS OF THE Ti-Zr-Ni ALLOYS BY THE “HYDRIDE CYCLE” METHOD
}

\author{
O.E. Dmytrenko ${ }^{1}$, I.V. Kolodiy ${ }^{1}$, T.B. Yanko ${ }^{2}$, V.M. Borysenko ${ }^{1}$, K. Irwin ${ }^{3}$, R.L. Vasilenko ${ }^{1}$ \\ ${ }^{1}$ National Science Center "Kharkov Institute of Physics and Technology”, Kharkiv, Ukraine; \\ ${ }^{2}$ PJCS “Titanium Institute”, Zaporizhzhya, Ukraine; \\ ${ }^{3}$ Quantum Gravity Research, Los Angeles, CA, USA \\ E-mail:dmitrenko@kipt.kharkov.ua
}

A comprehensive study of the technical parameters and conditions for the synthesis of ternary alloys in the Ti$\mathrm{Zr}-\mathrm{Ni}$ system by the "hydride cycle" method was carried out. The influence on the synthesis process of such parameters as: temperature and annealing time, heating rate, cooling conditions, material composition, dispersion, hydrogen content in the hydrides used, the presence of impurities, mixing and pressing methods, and the degree of pressing of the starting components was determined. The alloys of the following compositions were synthesized and investigated: $\mathrm{Ti}_{40.5} \mathrm{Zr}_{31.9} \mathrm{Ni}_{27.6}, \mathrm{Ti}_{41.5} \mathrm{Zr}_{41.5} \mathrm{Ni}_{17}, \mathrm{Ti}_{40} \mathrm{Zr}_{40} \mathrm{Ni}_{20}, \mathrm{Ti}_{44} \mathrm{Zr}_{40} \mathrm{Ni}_{16}$. The optimal technological parameters and conditions for the synthesis of ternary alloys are determined. It has been established that the key factors in the process of compound formation during hydride dissociation are the dispersion and homogeneity of the initial compacted components. It was found that the synthesis of ternary alloys in the Ti-Zr-Ni system occurs during a short-term exothermic reaction in the "thermal explosion" mode, which begins in the temperature region corresponding to the $\alpha \leftrightarrow \beta$ polymorphic transformation of zirconium and titanium.

PACS: 81.20.-n, 81.40.-z, 71.20.Lp

\section{INTRODUCTION}

Most zirconium alloys, including quasicrystalline (QC) materials and intermetallic compounds based on the Laves phase C14 L-TiZrNi, are capable of reversibly absorbing a significant amount of hydrogen and are promising materials for hydrogen energy. However, the production of these materials, due to the high melting point and chemical activity of the starting components, is a complex and energy-intensive task. Traditional methods for producing metal alloys, in this case, are significantly limited. It is necessary to use sophisticated vacuum equipment, which allows for noncrucible melting since molten titanium and zirconium actively interact with crucible materials. In this case, saturation with interstitial impurities also occurs, primarily with oxygen and nitrogen, which prevents the formation of a given structure due to the precipitation of phases stabilized by dissolved gas impurities [1-4]. Thus, the main methods for producing bulk Ti-Zr-Ni alloys are vacuum-arc and electron-beam melting. If it is necessary to obtain a QC material, additional heat treatment is required - quick quenching (melt spinning) [5] or long-term annealing, which allows one to finally obtain QC samples. Synthesizing large volumes of homogeneous samples in this way is technically difficult and expensive, which in turn limits further practical application.

The technology of the "hydride cycle" is based on the interaction of the products of thermal dissociation of hydrides of the starting components with the formation of systems and phases characteristic of these materials with significantly lower energy consumption. As shown in [6-12], this technique is successfully used for the synthesis of various binary and ternary alloys of refractory metals of the zirconium group. Including complex intermetallic compounds of the $\mathrm{Ti}-\mathrm{Zr}-\mathrm{Ni}$ system. Thus, the possibility of synthesizing stable
Ti-Zr-Ni quasicrystals was shown in [6]. For the successful synthesis of Ti-Zr-Ni system alloys with the given structural characteristics using this technology, it is necessary to establish a number of technological parameters. The main influencing factors are:

1. Heat treatment parameters: annealing temperature, annealing time, heating rate, pressure during annealing, cooling conditions.

2. The parameters of the starting components: material composition, dispersion, hydrogen content in the hydrides used, the presence of impurities.

3. Compaction parameters: method of mixing the starting components, method of compaction/pressing, degree of compression.

The aim of this work is to determine the optimal parameters and conditions for the synthesis of QC materials and intermetallic alloys of the $\mathrm{Ti}-\mathrm{Zr}-\mathrm{Ni}$ system.

\section{MATERIALS AND METHODS}

To conduct a study on the synthesis of QC materials and intermetallic alloys of the Ti-Zr-Ni system, samples of the following starting compositions (in at.\%) have been prepared:

1) $\mathrm{Ti}_{40.5} \mathrm{Zr}_{31.9} \mathrm{Ni}_{27.6}$ - this composition have been shown to strongly interact with $\mathrm{H}_{2}$ gas [4];

2) $\mathrm{Ti}_{41.5} \mathrm{Zr}_{41.5} \mathrm{Ni}_{17}$ - composition with experimentally confirmed formation of quasicrystals during melt spinning [5];

3) $\mathrm{Ti}_{40} \mathrm{Zr}_{40} \mathrm{Ni}_{20}$ - theoretically calculated optimal composition for the formation of the QC phase [13];

4) $\mathrm{Ti}_{44} \mathrm{Zr}_{40} \mathrm{Ni}_{16}$ - corresponds to the quasicrystals obtained by the technology of the "hydride cycle" [10].

Initial studies were carried out on samples of the composition $\mathrm{Ti}_{40.5} \mathrm{Zr}_{31.9} \mathrm{Ni}_{27.6}$. As the ranges, modes and indicators were refined, the study of samples of composition $\mathrm{Ti}_{41.5} \mathrm{Zr}_{41.5} \mathrm{Ni}_{17}$ and then $\mathrm{Ti}_{40} \mathrm{Zr}_{40} \mathrm{Ni}_{20} /$ $\mathrm{Ti}_{44} \mathrm{Zr}_{40} \mathrm{Ni}_{16}$ began. The following powders were used 
for all compositions under investigation: $\mathrm{Ti}$ - titanium powder Grade 1; $\mathrm{TiH}_{2}$ - titanium hydride powder (from TG-90, hydrogen content 3.6 wt.\%); $\mathrm{Zr}$ - zirconium powder PCRK-1; $\mathrm{ZrH}_{2}$ - zirconium hydride powder (from PCRK-1, hydrogen content 2.0 wt.\%); Ni - nickel powder electrolytic PNE-1; Ni-nickel powder carbonyl PNC. The powders were mixed by three different methods:

a) "drunk barrel" mixer for $60 \ldots 120 \mathrm{~min}$ at the rotational speed of $\sim 30 \ldots 40 \mathrm{rpm}$;

b) hand rubbing/mixing in alundum mortar;

c) high-energy grinding/mixing in a ball mill.

The obtained mixture of powders was compacted with the different degree of pressing: from 3 to $80 \mathrm{t}$ in the briquettes $\varnothing 15 \ldots 30 \mathrm{~mm}$ in diameter and height $6 . .25 \mathrm{~mm}$. Heat treatment in hydrogen (in the "thermal explosion" mode) was carried out by: heating to $450{ }^{\circ} \mathrm{C}$ in vacuum, hydrogen supply, holding for $1.5 \mathrm{~h}$ in a hydrogen atmosphere $(2 \ldots 5 \mathrm{~atm})$ at a constant temperature of $450{ }^{\circ} \mathrm{C}$. Cooling to room temperature under a hydrogen atmosphere for $2 \mathrm{~h}$. Annealing of all samples was carried out in a vacuum $(1 \ldots 5) \cdot 10^{-3} \mathrm{~Pa}$ at $700 \ldots 950^{\circ} \mathrm{C}$.

The structure and composition of the samples were studied by SEM and EDX microanalysis, using scanning electron microscope JSM 7001F with an accelerating voltage of $20 \mathrm{kV}$. Observation of the structure was carried out both in the secondary electron (SEI) mode and in the backscattered electron (COMPO) mode forming the composite image contrast. The composition was analyzed using the INCA PentaFET*3 detector and the Oxford Instruments INCA 4.11 program. To calibrate the quantitative analysis, a standard of cobalt with a purity of $99.99 \%$ was used. The mapping mode is used to determine the degree of distribution of elements over the sample. XRD studies of the sample were carried out using DRON-4-07 X-ray diffractometer in $\mathrm{Cu}-\mathrm{K} \alpha$ radiation. The initial components of the samples, as well as samples of $\mathrm{Ti}-\mathrm{Zr}$ $\mathrm{Ni}$ alloys after heat treatment in hydrogen (in the "thermal explosion" mode)/vacuum annealing, were investigated for desorption under vacuum heating in the temperature range $0 . .900{ }^{\circ} \mathrm{C}$ in a mass-spectrometer MX7203. The MX7203 mass-spectrometer is designed to determine the hydrogen present in alloys and the composition of the gas phase released from the material when heated in a vacuum.

\section{RESULT AND DISCUSSION 2.1. HEAT TREATMENT}

The key to the hydride cycle technology is heat treatment. Accordingly, the most significant parameter is temperature, heating and cooling rate, and also annealing time. Therefore, it is advisable to initially determine the effect of temperature and annealing time on the final structure of the synthesized samples and establish optimal conditions for the formation of a given structure. To determine the optimal annealing temperature of samples for the synthesis of quasicrystals, the temperature ranges of hydrogen desorption from the used starting components and their mixtures were determined (Fig. 1). This made it possible to determine the upper and lower boundaries of the dissociation of hydrides and, accordingly, to establish the annealing temperature of the samples.

From the literature data [14-17] it is known that hydrogen is able to saturate titanium to a limiting stoichiometric concentration of $4.04 \mathrm{wt} \%$, and zirconium above $2 \mathrm{wt} \%$, this is accompanied by significant changes in the properties of the material. The $\mathrm{H}_{2}$ content in the starting hydrides affects the properties of the resulting binary and ternary alloys (porosity, phase composition). This is due to the fact that during the dissociation of hydrides during heating in vacuum, $\mathrm{TiH}_{2}$ and $\mathrm{ZrH}_{2}$ produce hydrogen, and a decrease in the concentration of hydrogen in their crystal lattices leads to a sequence of phase transformations: $\mathrm{ZrH}_{2}(\varepsilon) \rightarrow$ $\mathrm{ZrH}_{2}(\delta) \rightarrow \mathrm{Zr}(\beta) \rightarrow \mathrm{Zr}(\alpha)$ and $\mathrm{TiH}_{2}(\varepsilon) \rightarrow \mathrm{TiH}_{2}(\delta) \rightarrow$ $\mathrm{Ti}(\beta) \rightarrow \mathrm{Ti}(\alpha)$. During dehydrogenation, both materials undergo a chain of phase transformations $\mathrm{MeH}_{2} \rightarrow \beta$ (bcc) $\rightarrow \alpha$ (hcp) [10]. However, the temperature ranges of phase transformations in the process of dehydrogenation for zirconium are $150 \ldots 200{ }^{\circ} \mathrm{C}$ higher than for titanium (see Fig. 1).

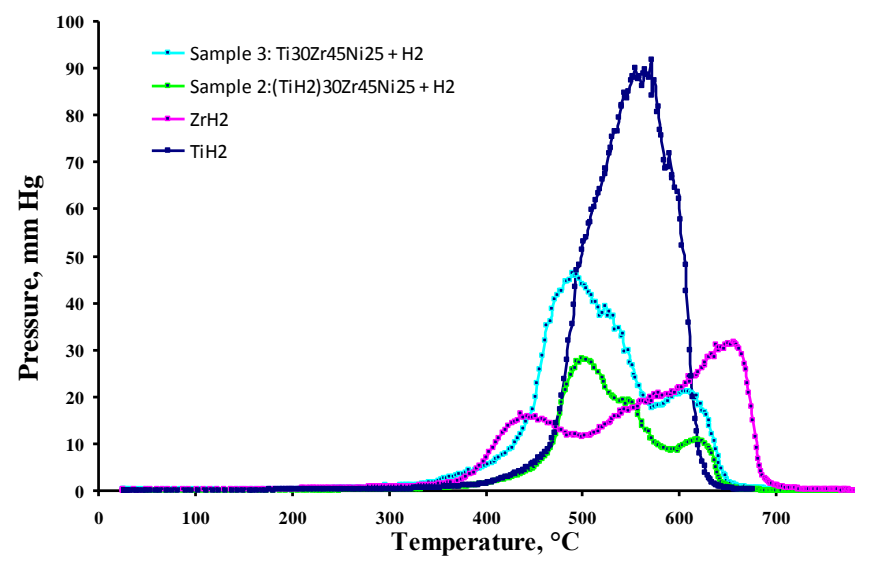

Fig. 1. Thermal desorption $\mathrm{TiH}_{2} ; \mathrm{ZrH}_{2}$; $\left(\mathrm{TiH}_{2}\right)_{40.5} \mathrm{Zr}_{31.9} \mathrm{Ni}_{27.6}+\mathrm{H}_{2} ; \mathrm{Ti}_{40.5} \mathrm{Zr}_{31.9} \mathrm{Ni}_{27.6}+\mathrm{H}_{2}$

In addition, it is necessary to take into account the allotropic (phase) transitions of each of the components of the sample, since they can affect the structure already formed during annealing. It is known that titanium exists in two crystalline modifications: hcp $\alpha$-Ti and bcc $\beta$-Ti (transition temperature $\alpha \leftrightarrow \beta=883^{\circ} \mathrm{C}$ ). Similarly, zirconium also has two crystalline modifications: hep $\alpha-\mathrm{Zr}$ and bcc $\beta-\mathrm{Zr}$ (transition temperature $\alpha \leftrightarrow \beta=863{ }^{\circ} \mathrm{C}$ ). Therefore, if the annealing temperature is higher than these values, then upon cooling of the sample, structural changes are possible due to polymorphic transformation. This will happen if $\mathrm{Ti}$ and $\mathrm{Zr}$ formed during "reductive" annealing did not fully interact with each other and with $\mathrm{Ni}$. Residues of $\beta$-Ti and $\beta-\mathrm{Zr}$, undergoing polymorphic transformation during cooling of the sample, can lead to a change in the structure of the formed triple alloy (quasicrystal). Therefore, the annealing time should be selected so that the reaction between the components is complete and a triple alloy is formed in the entire volume of the sample. This, in turn, is determined by diffusion processes (and, accordingly, the annealing temperature) and can be established empirically.

It should be remembered that according to the literature $[1,2,18,19]$, the icosahedral quasicrystals of 
the $\mathrm{Ti}-\mathrm{Zr}-\mathrm{Ni}$ system are stable at temperatures below $700{ }^{\circ} \mathrm{C}$; when heated above, the QC phase is converted to the Laves phase mixture L-TiZrNi, $\alpha-(\mathrm{Ti}, \mathrm{Zr})$ and phases $(\mathrm{Ti}, \mathrm{Zr})_{2} \mathrm{Ni}$. Therefore, the lower the sintering temperature, the greater the probability of maintaining the QC phase. In this case, the sintering regime should ensure that the process of the formation of the ternary alloy proceeds according to the solid-phase diffusion mechanism in full.

Thus, to choose the optimal annealing mode means to determine the heat treatment conditions under which:

- there was a complete dissociation of the starting hydrides;

- hydrogen is removed as much as possible from the material;

- hydride dissociation products completely interacted with each other and with the other components of the sample;

- formed a structural phase state characteristic of this composition;

- the processes of high-temperature evolution of the material are limited (aging, polymorphic transformations, precipitation of secondary phases, diffusion segregation, etc.).

From the graphs of thermal desorption shown in Fig. 1, it can be seen that the active evolution of hydrogen from $\mathrm{TiH}_{2}$ begins at $400{ }^{\circ} \mathrm{C}$ and practically ends above $650{ }^{\circ} \mathrm{C}$ with a maximum at $570{ }^{\circ} \mathrm{C} . \mathrm{ZrH}_{2}$ decomposition occurs in a wider temperature range of $300 \ldots 700{ }^{\circ} \mathrm{C}$ and has a two-stage character with peaks at 430 and $650{ }^{\circ} \mathrm{C}$. The graphs of thermal desorption from powder samples No. 2, 3 are similar and have several maxima, which represent the superposition of the decomposition processes of $\mathrm{TiH}_{2}$ and $\mathrm{ZrH}_{2}$, which is clearly visible on the general graph. Thus, it can be concluded that the main evolution of hydrogen from hydrides ends at $700{ }^{\circ} \mathrm{C}$; however, it is necessary to take into account that a certain amount of hydrogen is stored in $\mathrm{Ti}$ and $\mathrm{Zr}$ above $1000{ }^{\circ} \mathrm{C}$ [17]. Since the composition of $\mathrm{Ti}_{40.5} \mathrm{Zr}_{31.9} \mathrm{Ni}_{27.6}$ samples is eutectic, the upper limit of the annealing temperatures will be in the region of the eutectic formation. According to the double state diagrams for $\mathrm{Ti}-\mathrm{Ni}$ and $\mathrm{Zr}-\mathrm{Ni}$, the minimum eutectic temperature is 942 and $960{ }^{\circ} \mathrm{C}$, respectively. Thus, the temperature range for research is $700 \ldots 950{ }^{\circ} \mathrm{C}$.

\subsection{ANNEALING TEMPERATURE}

Initial studies were carried out on $\left(\mathrm{TiH}_{2}\right)_{40.5} \mathrm{Zr}_{31.9} \mathrm{Ni}_{27.6}$ and $\mathrm{Ti}_{40.5} \mathrm{Zr}_{31.9} \mathrm{Ni}_{27.6}$ samples treated in hydrogen in the "thermal explosion" mode followed by vacuum annealing at different temperatures. The XRD results of a series of samples of No. 1 after annealing at different temperatures showed that the minimum temperature required for the interaction of the starting components and the formation of ternary phases is $910{ }^{\circ} \mathrm{C}$ (with an annealing time of $1 \mathrm{~h}$ ). Previous experiments showed that the upper temperature is limited to $950{ }^{\circ} \mathrm{C}$, above which eutectic fusion of Ti and $\mathrm{Zr}$ with $\mathrm{Ni}$ occurs. Thus, the optimum temperature for sintering Ti-Zr-Ni samples with electrolytic nickel using the "hydride cycle" technology is $920 \ldots 930^{\circ} \mathrm{C}$. Electron microscopy of the $\left(\mathrm{TiH}_{2}\right)_{40.5} \mathrm{Zr}_{31.9} \mathrm{Ni}_{27.6}$ sample before and after heat treatment at different temperatures is presented in the COMPO mode in Fig. 2. It should be noted that in the No.1c diffraction pattern there are lines that can be attributed to the QC phase (at angles diffraction $2 \theta=36.5^{\circ}$ and $38.5^{\circ}$ ). But due to the weak intensity of the quasicrystal lines in the diffractogram, it is impossible to select a 5th order line to unambiguously confirm the QC phase in the sample. X-ray diffraction patterns of the samples are presented in Fig. 3. The results of the phase composition are summarized in Table 1.

The low nickel content in the starting powders is due to the uneven distribution of the starting components during transportation, due to a significant difference in the dispersion of the starting $\mathrm{TiH}_{2}, \mathrm{Zr}$ (up to $10 \mu \mathrm{m}$ ) and electrolytic Ni (up to $100 \mu \mathrm{m}$ ) (see Fig. 2,a). The mismatch of the initial composition during the XRD study does not affect the final composition of the synthesized sample, since, during the preparation of the samples, the mixing of the starting components occurs immediately before pressing. And the powder mixture is not compacted during transportation and the associated uneven distribution of components of different dispersion. However, the discovered phenomenon led to the study of the effect of the degree of dispersion of the components and mixing methods on the synthesis of the $\mathrm{Ti}-\mathrm{Zr}-\mathrm{Ni}$ ternary alloy and the formation of the structure.

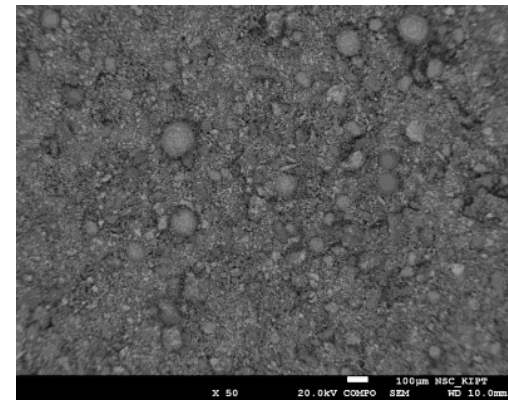

$a$

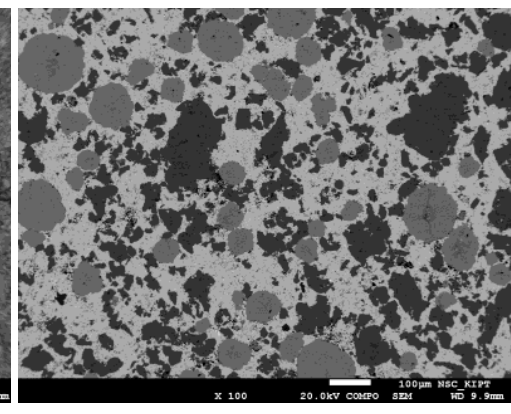

$b$

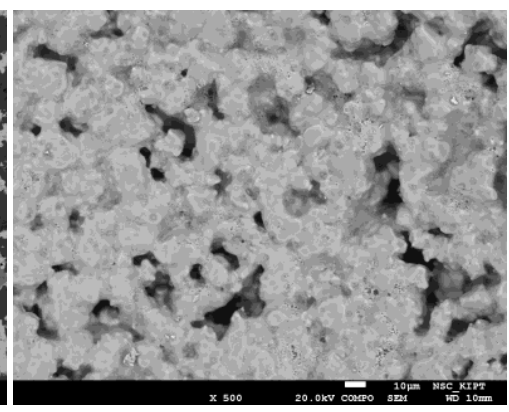

Fig. 2. Electron microscopy of the sample $\left(\mathrm{TiH}_{2}\right)_{40.5} \mathrm{Zr}_{31.9} \mathrm{Ni}_{27.6}+\mathrm{H}_{2}$ before and after heat treatment: $a$-powder sample No. la; $b$-sample No. lc after annealing at $700{ }^{\circ} \mathrm{C}$ for $1 \mathrm{~h}+910^{\circ} \mathrm{C}$ for $1 \mathrm{~h}$; $c$-sample No. Id after annealing at $920^{\circ} \mathrm{C}$ for $1 \mathrm{~h}$ 
Table 1

Phase composition of the studied samples $\mathrm{Ti}_{40.5} \mathrm{Zr}_{31.9} \mathrm{Ni}_{27.6}$

\begin{tabular}{|c|c|c|c|c|}
\hline Sample & $\begin{array}{c}\text { Heat } \\
\text { treatment } \\
\text { mode } \\
\end{array}$ & Phase & $\begin{array}{l}\text { Weight content, } \\
\text { wt. } \%\end{array}$ & Lattice parameters, $\AA$ \\
\hline \multirow{3}{*}{$\begin{array}{l}\text { No. 1a }\left(\mathrm{TiH}_{2}\right)_{40.5} \mathrm{Zr}_{31.9} \mathrm{Ni}_{27.6} \\
\mathrm{TiH}_{2}, \mathrm{Zr}, \mathrm{PNE}-1\end{array}$} & \multirow{3}{*}{ powder $+\mathrm{H}_{2}$} & $\mathrm{TiH}_{2}$ & 28.6 & $\mathrm{a}=4.452$ \\
\hline & & $\mathrm{ZrH}_{2}-\varepsilon$ & 62.9 & $\mathrm{a}=3.515 ; \mathrm{c}=4.475$ \\
\hline & & $\mathrm{Ni}$ & 8.5 & $\mathrm{a}=3.524$ \\
\hline \multirow{5}{*}{$\begin{array}{l}\text { No. } 1 \mathrm{~b}\left(\mathrm{TiH}_{2}\right)_{40.5} \mathrm{Zr}_{31.9} \mathrm{Ni}_{27.6} \\
\mathrm{TiH}_{2}, \mathrm{Zr}, \mathrm{PNE}-1\end{array}$} & \multirow{5}{*}{$910^{\circ} \mathrm{C}, 1 \mathrm{~h}$} & Ti- $\alpha$ & 19.9 & $\mathrm{a}=2.962 ; \mathrm{c}=4.740$ \\
\hline & & $\mathrm{Zr}-\alpha$ & 45.2 & $a=3.245 ; c=5.169$ \\
\hline & & $\mathrm{Ni}$ & 5.2 & $\mathrm{a}=3.526$ \\
\hline & & $\mathrm{ZrH}_{2}-\delta$ & 24.1 & $\mathrm{a}=4.780$ \\
\hline & & $\mathrm{NiTiO}_{3}$ & 5.6 & $\mathrm{a}=5.469 ; \alpha=55.37^{\circ}$ \\
\hline \multirow{4}{*}{$\begin{array}{l}\text { No. } 1 \mathrm{c}\left(\mathrm{TiH}_{2}\right)_{40.5} \mathrm{Zr}_{31.9} \mathrm{Ni}_{27.6} \\
\mathrm{TiH}_{2}, \mathrm{Zr}, \mathrm{PNE}-1\end{array}$} & \multirow{4}{*}{$\begin{array}{r}700^{\circ} \mathrm{C}, 1 \mathrm{~h}+ \\
910^{\circ} \mathrm{C}, 1 \mathrm{~h}\end{array}$} & $\mathrm{Ni}$ & - & $a=3.524$ \\
\hline & & $\mathrm{Zr}-\alpha$ & - & $\mathrm{a}=3.232 ; \mathrm{c}=5.147$ \\
\hline & & $(\mathrm{Ti}, \mathrm{Zr})_{2} \mathrm{Ni}$ & - & $\mathrm{a}=11.899$ \\
\hline & & QC-? & - & - \\
\hline \multirow{2}{*}{$\begin{array}{l}\text { No. } 1 \mathrm{~d}\left(\mathrm{TiH}_{2}\right)_{40.5} \mathrm{Zr}_{31.9} \mathrm{Ni}_{27.6}, \\
\mathrm{TiH}_{2}, \mathrm{Zr}, \mathrm{PNE}-1\end{array}$} & \multirow{2}{*}{$920^{\circ} \mathrm{C}, 1 \mathrm{~h}$} & $(\mathrm{Ti}, \mathrm{Zr})_{2} \mathrm{Ni}$ & 74.2 & $\mathrm{a}=11.813$ \\
\hline & & L-TiZrNi & 25.8 & $\mathrm{a}=5.222 ; \mathrm{c}=8.537$ \\
\hline \multirow{3}{*}{$\begin{array}{l}\text { No. 1e } \mathrm{Ti}_{40,5} \mathrm{Zr}_{31,9} \mathrm{Ni}_{27,6} \text {, } \\
\mathrm{Ti}, \mathrm{Zr}, \mathrm{PNE}-1\end{array}$} & \multirow{3}{*}{ powder $+\mathrm{H}_{2}$} & $\mathrm{TiH}_{2}$ & 30.6 & $\mathrm{a}=4.453$ \\
\hline & & $\mathrm{ZrH}_{2}-\varepsilon$ & 55.2 & $\mathrm{a}=3.518 ; \mathrm{c}=4.462$ \\
\hline & & $\mathrm{Ni}$ & 14.2 & $\mathrm{a}=3.524$ \\
\hline \multirow{2}{*}{$\begin{array}{l}\text { No. 1f } \mathrm{Ti}_{40.5} \mathrm{Zr}_{31.9} \mathrm{Ni}_{27.6}, \\
\mathrm{Ti}, \mathrm{Zr}, \mathrm{PNE}-1\end{array}$} & \multirow{2}{*}{$920^{\circ} \mathrm{C}, 1 \mathrm{~h}$} & $(\mathrm{Ti}, \mathrm{Zr})_{2} \mathrm{Ni}$ & 93.6 & $\mathrm{a}=11.820$ \\
\hline & & L-TiZrNi & 6.4 & $\mathrm{a}=5.218 ; \mathrm{c}=8.545$ \\
\hline \multirow{2}{*}{$\begin{array}{l}\text { No. } 1 \mathrm{~g} \mathrm{Ti} \mathrm{Ti}_{40.5} \mathrm{Zr}_{31.9} \mathrm{Ni}_{27.6} \text {, } \\
\mathrm{Ti}, \mathrm{Zr}, \mathrm{PNE}-1\end{array}$} & \multirow{2}{*}{$930^{\circ} \mathrm{C}, 1 \mathrm{~h}$} & $(\mathrm{Ti}, \mathrm{Zr})_{2} \mathrm{Ni}$ & 79.6 & $\mathrm{a}=11.864$ \\
\hline & & L-TiZrNi & 20.4 & $\mathrm{a}=5.223 ; \mathrm{c}=8.556$ \\
\hline \multirow{2}{*}{$\begin{array}{l}\text { No. } 1 \mathrm{~h} \mathrm{Ti} \mathrm{Ti}_{40.5} \mathrm{Zr}_{31.9} \mathrm{Ni}_{27.6} \text {, } \\
\mathrm{Ti}, \mathrm{Zr}, \mathrm{PNE}-1\end{array}$} & \multirow{2}{*}{$940^{\circ} \mathrm{C}, 1 \mathrm{~h}$} & $(\mathrm{Ti}, \mathrm{Zr})_{2} \mathrm{Ni}$ & 92.1 & $\mathrm{a}=11.845$ \\
\hline & & L-TiZrNi & 7.9 & $\mathrm{a}=5.232 ; \mathrm{c}=8.558$ \\
\hline $\begin{array}{l}\text { No. } 1 \mathrm{j} \\
\left(\mathrm{TiH}_{2}\right)_{40.5}\left(\mathrm{ZrH}_{2}\right)_{31.9} \mathrm{Ni}_{27.6} \text {, } \\
\mathrm{TiH}_{2}, \mathrm{ZrH}_{2}, \mathrm{PNE}-1\end{array}$ & $\begin{array}{c}920 \ldots 930^{\circ} \mathrm{C}, \\
1 \mathrm{~h}\end{array}$ & $(\mathrm{Ti}, \mathrm{Zr})_{2} \mathrm{Ni}$ & 72.8 & $\mathrm{a}=11.791$ \\
\hline
\end{tabular}

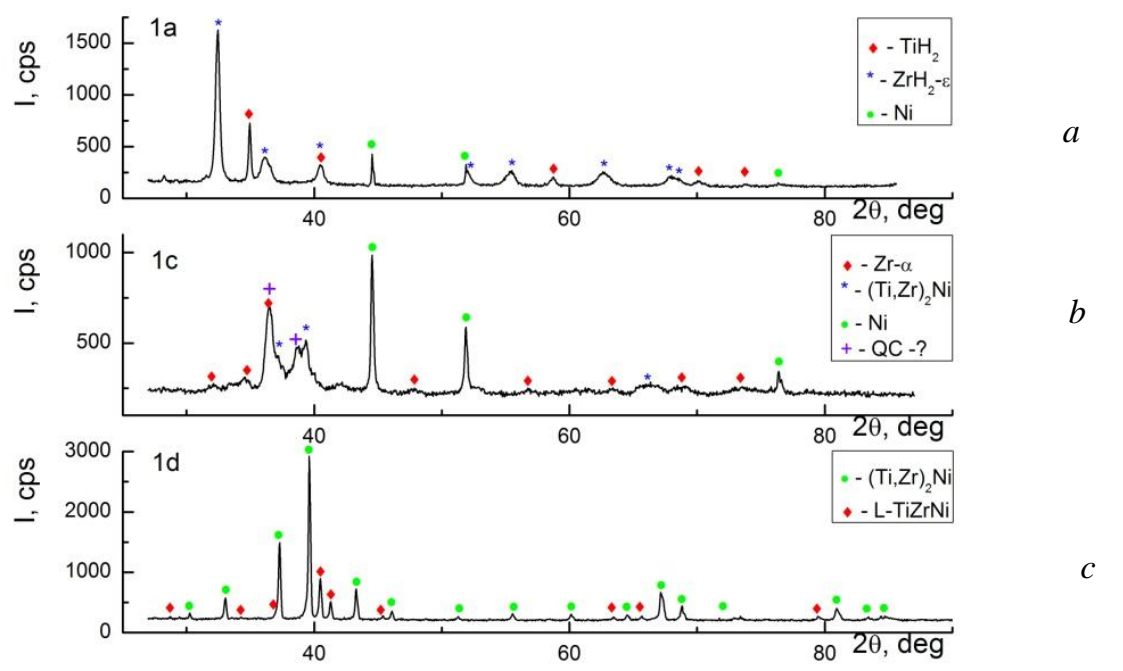

Fig. 3. X-ray diffraction patterns of samples $\left(\mathrm{TiH}_{2}\right)_{40.5} \mathrm{Zr}_{31.9} \mathrm{Ni}_{27.6}: a$ - powder sample No. $1 \mathrm{a} ; \mathrm{b}-$ sample No. $1 \mathrm{c}$ after annealing at $700{ }^{\circ} \mathrm{C}$ for $1 \mathrm{~h}+910^{\circ} \mathrm{C}$ for $1 \mathrm{~h}$; c-sample No. Id after annealing at $920{ }^{\circ} \mathrm{C}$ for $1 \mathrm{~h}$

\subsection{DISPERSION OF INITIAL COMPONENTS}

Fine samples of $\mathrm{TiH}_{2}, \mathrm{ZrH}_{2}, \mathrm{Zr}$ with a size of $(0.1 \ldots 10 \mu \mathrm{m})$ and two types of nickel powder were used to prepare the samples. The first is electrolytic nickel of the PNE-1 brand, which was sieved through a series of sieves, for separation into fractions, the fine and coarse fractions were used separately (less than 40 and more than $100 \mu \mathrm{m}$, respectively). The second is carbonyl nickel with a particle size of $0.1 \ldots 10 \mu \mathrm{m}$. Studies have shown that the difference in the dispersion of $\mathrm{Ti}, \mathrm{Zr}, \mathrm{Ni}$ leads to local inhomogeneities, which give a significant deviation from a given composition in small areas of the analysis. Therefore, it is necessary to use the initial components of the same dispersion and minimum size. This will allow to achieve uniform distribution of elements along the sample, increase contact zones and accelerate the process of formation of a triple alloy. Thus, the use of finely dispersed nickel made it possible 
to achieve greater phase homogeneity of the samples and to lower the sintering temperature of the samples with the formation of the alloy by $50{ }^{\circ} \mathrm{C}$.

Further studies were conducted on samples of a different composition. According to published data [5], the composition of $\mathrm{Ti}_{41.5} \mathrm{Zr}_{41.5} \mathrm{Ni}_{17}$ is optimal (experimentally confirmed) for the synthesis of stable quasicrystals in the Ti-Zr-Ni system. In addition, $\mathrm{ZrH}_{2}$ powder (instead of zirconium powder) and the sieved fine fraction of nickel PNE-1 (less than $40 \mu \mathrm{m}$ in size) were used as starting components. X-ray diffraction patterns of the samples are presented in Fig. 4, the results of the phase composition are summarized in Table 2. Electron microscopy of the cleavage of the $\left(\mathrm{TiH}_{2}\right)_{41.5}\left(\mathrm{ZrH}_{2}\right)_{41.5} \mathrm{Ni}_{17}$ sample after annealing at $930{ }^{\circ} \mathrm{C}$ for $1 \mathrm{~h}$ is presented in Fig. 5 .

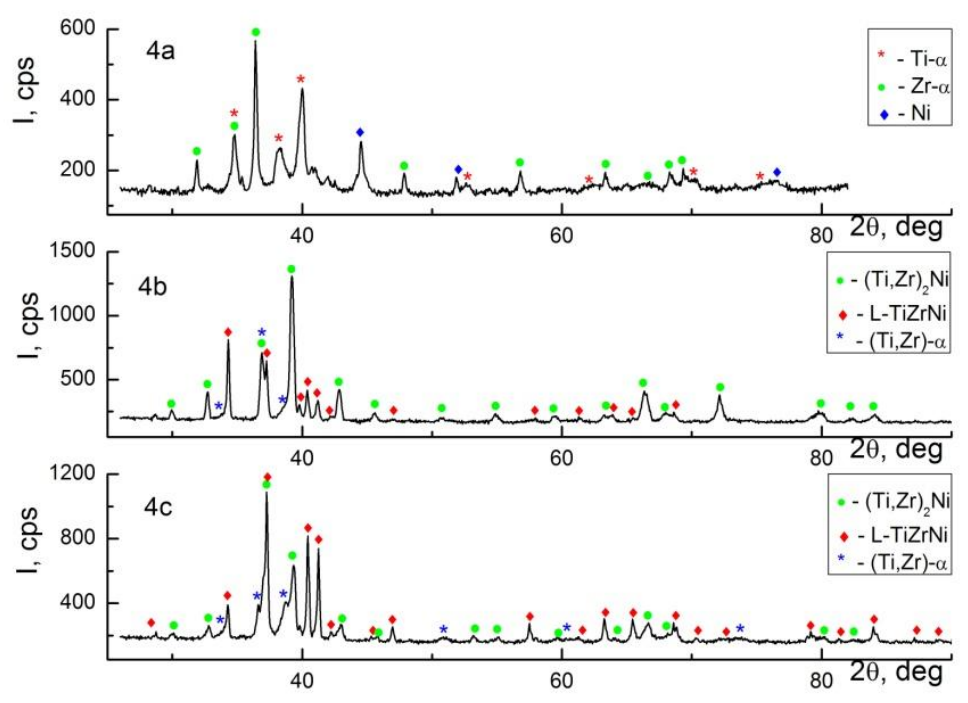

Fig. 4. X-ray diffraction patterns of samples $\left(\mathrm{TiH}_{2}\right)_{40} \mathrm{Zr}_{40} \mathrm{Ni}_{20}$ : No. $4 a, 4 b, 4 c$
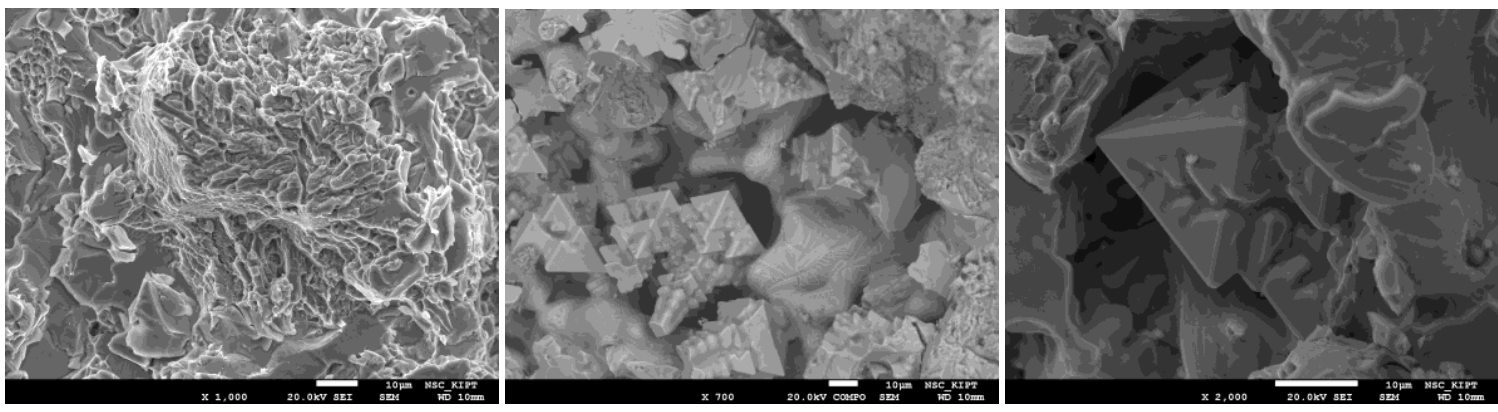

Fig. 5. Electron microscopy samples $\left(\mathrm{TiH}_{2}\right)_{41.5}\left(\mathrm{ZrH}_{2}\right)_{41.5} \mathrm{Ni} \mathrm{i}_{17}$ after annealing at $930{ }^{\circ} \mathrm{C}$, for $1 \mathrm{~h}$

As can be seen from the XRD analysis data presented in Table 2, the use of a finely divided fraction of electrolytic nickel (samples No. 2a-2d) led to a noticeable decrease in the temperature of the solid phase sintering. However, a change in the composition to the optimal one for the synthesis of the QC phase did not affect the phase composition of the samples. X-ray diffraction analysis confirmed only the presence of crystalline phases: L-TiZrNi, $(\mathrm{Ti}, \mathrm{Zr})_{2} \mathrm{Ni}$ and $\alpha$-(Ti,Zr). In sample $2 \mathrm{c}$, a halo is present in the diffraction pattern in the range of angles $2 \theta \approx 30 \ldots 42^{\circ}$, which indicates the presence of an X-ray amorphous phase in the sample. No hydrides were detected in the sample, i.e., hydrogen left the sample, but this temperature is not enough for synthesis. Also on this diffraction pattern, there are lines that can be interpreted as a quasicrystal, but the presence of a halo prevents unambiguous identification. Therefore, the presence of a QC phase is not given.

\subsection{HYDROGEN CONTENT IN THE HYDRIDES}

The use of $\mathrm{TiH}_{2}$ as initial components with different hydrogen contents $(2 \ldots 3.6$ wt.\%) did not affect the structural phase composition of the final samples. As well as the combined use of $\mathrm{TiH}_{2}$ and $\mathrm{ZrH}_{2}$ (series No. 2). Regardless of the weight content of hydrogen in hydrides (or one/both hydrides are present in the mixture), a similar alloy structure is formed after annealing in a vacuum. The amount of hydrogen in the initial hydrides significantly affects the time it takes to reach the heat treatment mode. The more hydrogen in the initial charge, the longer the dehydrogenation process before sintering the sample.

\subsection{DURATION OF ANNEALING}

Experiments were carried out to study the effect of the duration of isothermal annealing in a vacuum on the structural phase state of the obtained samples. The duration of annealing ranged from 2 to $15 \mathrm{~h}$ at a temperature of $800{ }^{\circ} \mathrm{C}$. From the data given in Table 2 (No. $4 \mathrm{a}, 4 \mathrm{~d}$, and $6 \mathrm{a}$, respectively), it follows that this temperature is not sufficient for the synthesis of a ternary alloy, regardless of the annealing duration. After prolonged annealing in vacuum, the samples are a mixture of $\mathrm{Ti}, \mathrm{Zr}$, Ni with a small amount of $(\mathrm{Ti}, \mathrm{Zr})_{2} \mathrm{Ni}$. 
Phase composition of samples $\mathrm{Ti}_{41.5} \mathrm{Zr}_{41.5} \mathrm{Ni}_{17} / \mathrm{Ti}_{40} \mathrm{Zr}_{40} \mathrm{Ni}_{20} / \mathrm{Ti}_{44} \mathrm{Zr}_{40} \mathrm{Ni}_{16}$ under various synthesis conditions

\begin{tabular}{|c|c|c|c|c|}
\hline Sample & $\begin{array}{l}\text { Heat treatment } \\
\text { mode }\end{array}$ & Phase & $\begin{array}{c}\text { Weight content, } \\
\text { wt, } \%\end{array}$ & Lattice parameters, $\AA$ \\
\hline \multirow{2}{*}{$\begin{array}{l}\text { No. } 2 \mathrm{a} \\
\left(\mathrm{TiH}_{2}\right)_{41.5}\left(\mathrm{ZrH}_{2}\right)_{41.5} \mathrm{Ni}_{17} \text {, } \\
\mathrm{TiH}_{2}, \mathrm{ZrH}_{2}, \text { fine PNE-1 }\end{array}$} & \multirow[b]{2}{*}{$930^{\circ} \mathrm{C}, 1 \mathrm{~h}$} & $(\mathrm{Ti}, \mathrm{Zr})_{2} \mathrm{Ni}$ & 89.9 & $\mathrm{a}=11.965$ \\
\hline & & L-TiZrNi & 10.1 & $\mathrm{a}=5.226 ; \mathrm{c}=8.622$ \\
\hline \multirow{3}{*}{$\begin{array}{l}\text { No. 2b } \\
\left(\mathrm{TiH}_{2}\right)_{41.5}\left(\mathrm{ZrH}_{2}\right)_{41.5} \mathrm{Ni}_{17} \text {, } \\
\mathrm{TiH}_{2}, \mathrm{ZrH}_{2}, \text { fine PNE-1 }\end{array}$} & \multirow{3}{*}{$920^{\circ} \mathrm{C}, 1 \mathrm{~h}$} & $(\mathrm{Ti}, \mathrm{Zr})_{2} \mathrm{Ni}$ & 70.8 & $\mathrm{a}=12.004$ \\
\hline & & L-TiZrNi & 8.8 & $\mathrm{a}=5.238 ; \mathrm{c}=8.675$ \\
\hline & & $(\mathrm{Ti}, \mathrm{Zr})-\alpha$ & 20.4 & $\mathrm{a}=3.076 ; \mathrm{c}=4.918$ \\
\hline \multirow{3}{*}{$\begin{array}{l}\text { No. 2c } \\
\left(\mathrm{TiH}_{2}\right)_{41.5}\left(\mathrm{ZrH}_{2}\right)_{41.5} \mathrm{Ni}_{17} \text {, } \\
\mathrm{TiH}_{2}, \mathrm{ZrH}_{2}, \text { fine PNE-1 }\end{array}$} & \multirow{3}{*}{$850^{\circ} \mathrm{C}, 1 \mathrm{~h}$} & $\mathrm{Ni}$ & - & $\mathrm{a}=3.521$ \\
\hline & & $\mathrm{Zr}-\alpha$ & - & $\mathrm{a}=3.232 ; \mathrm{c}=5.148$ \\
\hline & & Ti- $\alpha$ & - & $\mathrm{a}=2.951 ; \mathrm{c}=4.686$ \\
\hline \multirow{3}{*}{$\begin{array}{l}\text { No. } 2 \mathrm{~d} \\
\left(\mathrm{TiH}_{2}\right)_{41.5}\left(\mathrm{ZrH}_{2}\right)_{41.5} \mathrm{Ni}_{17} \text {, } \\
\mathrm{TiH}_{2}, \mathrm{ZrH}_{2}, \text { fine PNE-1 }\end{array}$} & \multirow{3}{*}{$870^{\circ} \mathrm{C}, 1.5 \mathrm{~h}$} & $(\mathrm{Ti}, \mathrm{Zr})_{2} \mathrm{Ni}$ & 84.1 & $\mathrm{a}=11.970$ \\
\hline & & L-TiZrNi & 2.9 & $\mathrm{a}=5.231 ; \mathrm{c}=8.578$ \\
\hline & & $(\mathrm{Ti}, \mathrm{Zr})-\alpha$ & 13.0 & $\mathrm{a}=3.064 ; \mathrm{c}=4.910$ \\
\hline \multirow{3}{*}{ 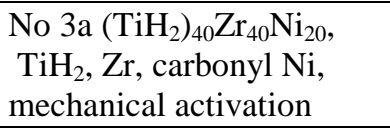 } & \multirow{3}{*}{$\begin{array}{l}910 \ldots 915^{\circ} \mathrm{C} \\
2 \mathrm{~h} 10 \mathrm{~min}\end{array}$} & $(\mathrm{Ti}, \mathrm{Zr})_{2} \mathrm{Ni}$ & 62.4 & $\mathrm{a}=11.970$ \\
\hline & & L-TiZrNi & 32.3 & $\mathrm{a}=5.233 ; \mathrm{c}=8.568$ \\
\hline & & $(\mathrm{Ti}, \mathrm{Zr})-\alpha$ & 5.3 & $\mathrm{a}=3.088 ; \mathrm{c}=4.898$ \\
\hline \multirow{3}{*}{$\begin{array}{l}\text { No. } 3 \mathrm{~b}\left(\mathrm{TiH}_{2}\right)_{44} \mathrm{Zr}_{40} \mathrm{Ni}_{16}, \\
\mathrm{TiH}_{2}, \mathrm{Zr} \text {, carbonyl Ni, } \\
\text { mechanical activation }\end{array}$} & \multirow{3}{*}{$\begin{array}{l}910 \ldots 915^{\circ} \mathrm{C} \\
2 \mathrm{~h} 10 \mathrm{~min}\end{array}$} & $(\mathrm{Ti}, \mathrm{Zr})_{2} \mathrm{Ni}$ & 52.7 & $\mathrm{a}=11.974$ \\
\hline & & L-TiZrNi & 26.3 & $\mathrm{a}=5.240 ; \mathrm{c}=8.560$ \\
\hline & & $(\mathrm{Ti}, \mathrm{Zr})-\alpha$ & 21.0 & $\mathrm{a}=3.073 ; \mathrm{c}=4.896$ \\
\hline \multirow{4}{*}{$\begin{array}{l}\text { No. } 4 \mathrm{a}\left(\mathrm{TiH}_{2}\right)_{40} \mathrm{Zr}_{40} \mathrm{Ni}_{20}, \\
\mathrm{TiH}_{2}, \mathrm{Zr} \text {, carbonyl Ni, } \\
\text { mechanical activation }\end{array}$} & \multirow{4}{*}{$800^{\circ} \mathrm{C}, 2 \mathrm{~h}$} & Ti- $\alpha$ & $\sim 60$ & $\mathrm{a}=2.975 ; \mathrm{c}=4.698$ \\
\hline & & $\mathrm{Zr}-\alpha$ & $\sim 27$ & $\mathrm{a}=3.238 ; \mathrm{c}=5.152$ \\
\hline & & $\mathrm{Ni}$ & $\sim 13$ & $\mathrm{a}=3.524$ \\
\hline & & $\mathrm{X}$ & - & $? ? ?$ \\
\hline \multirow{3}{*}{$\begin{array}{l}\text { No. } 4 \text { b }\left(\mathrm{TiH}_{2}\right) \mathrm{Zr}_{40} \mathrm{Ni}_{20}, \\
\mathrm{TiH} \\
\text { mechanical activation }\end{array}$} & \multirow{3}{*}{$870^{\circ} \mathrm{C}, 2 \mathrm{~h}$} & $(\mathrm{Ti}, \mathrm{Zr})_{2} \mathrm{Ni}$ & 57.6 & $\mathrm{a}=11.935$ \\
\hline & & L-TiZrNi & 31.1 & $\mathrm{a}=5.230 ; \mathrm{c}=8.560$ \\
\hline & & $(\mathrm{Ti}, \mathrm{Zr})-\alpha$ & 11.3 & $\mathrm{a}=3.069 ; \mathrm{c}=4.824$ \\
\hline \multirow{3}{*}{$\begin{array}{l}\text { No. } 4 \mathrm{c}\left(\mathrm{TiH}_{2}\right) \mathrm{Zr}_{40} \mathrm{Ni}_{20}, \\
\mathrm{TiH}_{2}, \mathrm{Zr} \text {, carbonyl Ni, } \\
\text { mechanical activation }\end{array}$} & \multirow{3}{*}{$\begin{array}{l}800^{\circ} \mathrm{C}, 2 \mathrm{~h}+ \\
\mathrm{EBM}\end{array}$} & $(\mathrm{Ti}, \mathrm{Zr})_{2} \mathrm{Ni}$ & 29.9 & $\mathrm{a}=11.907$ \\
\hline & & L-TiZrNi & 53.7 & $\mathrm{a}=5.230 ; \mathrm{c}=8.548$ \\
\hline & & $(\mathrm{Ti}, \mathrm{Zr})-\alpha$ & 16.4 & $\mathrm{a}=3.054 ; \mathrm{c}=4.898$ \\
\hline \multirow{4}{*}{$\begin{array}{l}\text { No. } 4 \mathrm{~d}\left(\mathrm{TiH}_{2}\right)_{44} \mathrm{Zr}_{40} \mathrm{Ni}_{16} \text {, } \\
\mathrm{TiH}_{2}, \mathrm{Zr} \text {, carbonyl Ni, } \\
\text { mechanical activation }\end{array}$} & \multirow{4}{*}{$830^{\circ} \mathrm{C}, 2.5 \mathrm{~h}$} & Ti- $\alpha$ & $\sim 35$ & $\mathrm{a}=2.975 ; \mathrm{c}=4.698$ \\
\hline & & $\mathrm{Zr}-\alpha$ & $\sim 50$ & $\mathrm{a}=3.232 ; \mathrm{c}=5.147$ \\
\hline & & $\mathrm{Ni}$ & $\sim 15$ & $\mathrm{a}=3.514$ \\
\hline & & $\mathrm{X}$ & - & $? ? ?$ \\
\hline \multirow{3}{*}{$\begin{array}{l}\text { No. } 4 \mathrm{e}\left(\mathrm{TiH}_{2}\right)_{44} \mathrm{Zr}_{40} \mathrm{Ni}_{16} \\
\mathrm{TiH}_{2}, \mathrm{Zr} \text {, carbonyl Ni, } \\
\text { mechanical activation }\end{array}$} & \multirow{3}{*}{$\begin{array}{l}830^{\circ} \mathrm{C}, 2.5 \mathrm{~h} \\
+\mathrm{EBM}\end{array}$} & $(\mathrm{Ti}, \mathrm{Zr})_{2} \mathrm{Ni}$ & 16.0 & $\mathrm{a}=11.965$ \\
\hline & & L-TiZrNi & 61.0 & $\mathrm{a}=5.251 ; \mathrm{c}=8.589$ \\
\hline & & $(\mathrm{Ti}, \mathrm{Zr})-\alpha$ & 23.0 & $\mathrm{a}=3.087 ; \mathrm{c}=4.906$ \\
\hline \multirow{3}{*}{$\begin{array}{l}\text { No. 5a }\left(\mathrm{TiH}_{2}\right)_{41.5} \mathrm{Zr}_{41.5} \mathrm{Ni}_{17} \\
\mathrm{TiH}_{2}, \mathrm{Zr} \text {, carbonyl Ni}\end{array}$} & & $(\mathrm{Ti}, \mathrm{Zr})_{2} \mathrm{Ni}$ & 72.8 & $\mathrm{a}=11.985$ \\
\hline & $900^{\circ} \mathrm{C}$ & L-TiZrNi & 11.0 & $\mathrm{a}=5.237 ; \mathrm{c}=8.581$ \\
\hline & & $(\mathrm{Ti}, \mathrm{Zr})-\alpha$ & 16.2 & $\mathrm{a}=3.075 ; \mathrm{c}=4.894$ \\
\hline & & $(\mathrm{Ti}, \mathrm{Zr})_{2} \mathrm{Ni}$ & 60.2 & $\mathrm{a}=11.978$ \\
\hline No. 5 b $\left(\mathrm{IlH}_{2}\right)_{41.5} \mathrm{Zr}_{41.5} \mathrm{N1}_{17}$ & $900{ }^{\circ} \mathrm{C}, 3 \mathrm{~h}$ & L-TiZrNi & 12.6 & $\mathrm{a}=5.231 ; \mathrm{c}=8.590$ \\
\hline & & $(\mathrm{Ti}, \mathrm{Zr})-\alpha$ & 27.2 & $\mathrm{a}=3.067 ; \mathrm{c}=4.872$ \\
\hline & & $(\mathrm{Ti}, \mathrm{Zr})_{2} \mathrm{Ni}$ & 51.8 & $a=11.964$ \\
\hline No. $5 \mathrm{c}\left(\mathrm{T}_{1} \mathrm{H}_{2}\right)_{41.5} \mathrm{Zr}_{41.5} \mathrm{N1}_{17}$ & $8 / 0 \ldots 880^{\circ} \mathrm{C}$ & L-TiZrNi & 19.2 & $\mathrm{a}=5.241 ; \mathrm{c}=8.577$ \\
\hline $11 \mathrm{H}_{2}, \mathrm{Zr}$, carbonyl N1 & & $(\mathrm{Ti}, \mathrm{Zr})-\alpha$ & 29.0 & $\mathrm{a}=3.073 ; \mathrm{c}=4.853$ \\
\hline No. $6 \mathrm{a} \mathrm{Ti}_{44} \mathrm{Zr}_{40}(\mathrm{Ni}-\mathrm{Pd})_{16}$ & & Ti- $\alpha$ & 23.2 & $\mathrm{a}=2.942 ; \mathrm{c}=4.679$ \\
\hline $\mathrm{TiH}_{2}, \mathrm{Zr}$, fine PNE-1 with & $680 \ldots 800^{\circ} \mathrm{C}$ & $\mathrm{Zr}-\alpha$ & 42.0 & $\mathrm{a}=3.229 ; \mathrm{c}=5.141$ \\
\hline chemically precipitated & $\sim 15 \mathrm{~h}$ & $\mathrm{Ni}$ & 23.7 & $\mathrm{a}=3.507$ \\
\hline $\mathrm{Pd} \sim 1$ wt. $\%$ & & $(\mathrm{Ti}, \mathrm{Zr})_{2} \mathrm{Ni}$ & 11.1 & $\mathrm{a}=11.964$ \\
\hline
\end{tabular}

With increasing annealing temperature to $910^{\circ} \mathrm{C}$, there is no significant difference in the structure (after 2 and $3 \mathrm{~h}$ of isothermal annealing in a vacuum). The resulting samples have a similar structure. This is confirmed by XRD data on the example of sample $\mathrm{Ti}_{41.5} \mathrm{Zr}_{41.5} \mathrm{Ni}_{17}$ (see Table 2, No. 5a, 5b). Thus, based on the XRD results of all synthesized samples, we can conclude that in the temperature range of $870 \ldots 900{ }^{\circ} \mathrm{C}$, an isothermal exposure of $60 \mathrm{~min}$ is sufficient for the complete formation of the final structure. When using the initial finely dispersed components with a size of $1 \ldots 10 \mu \mathrm{m}$, it is first of all important to use finely 
dispersed nickel. When using coarse particles, for example, electrolytic nickel larger than $100 \mu \mathrm{m}$, for the formation of a ternary alloy, it is necessary to increase the sintering temperature to $920 \ldots 930{ }^{\circ} \mathrm{C}$.

\subsection{HEATING RATE}

The heating rate significantly affects the dissociation temperature of titanium and zirconium hydrides. The higher the heating rate, the stronger the peak of thermal desorption shifts from the initial $\mathrm{TiH}_{2}$ and $\mathrm{ZrH}_{2}$ to the region of higher temperatures. As shown by experiments with rapid heating at a rate of more than $10{ }^{\circ} \mathrm{C} / \mathrm{min}$ after $400{ }^{\circ} \mathrm{C}$, intense gas evolution from the samples begins and the vacuum pumping system cannot cope with the released hydrogen. In addition, the intense release of $\mathrm{H}_{2}$ upon rapid heating leads to the formation of large pores in the sample and its swelling. Conversely, with slow heating at a rate of not more than $5{ }^{\circ} \mathrm{C} / \mathrm{min}$, the sample after sintering has a significantly lower porosity with a pore size of less than $0.5 \mathrm{~mm}$ (unlike large pores with a size of up to $5 \mathrm{~mm}$ with rapid heating). Thus, it was found that the optimum heating rate is $5^{\circ} \mathrm{C} / \mathrm{min}$.

\subsection{PRESSURE DURING ANNEALING}

The pressure in the chamber during sintering is also directly related to the dissociation rate of hydrides and the removal of hydrogen from the samples and, consequently, to the formation of a ternary alloy. The better the vacuum during heat treatment, the faster the cast structure is formed. In addition, the best vacuum conditions favorably affect the cleaning of the processed material from volatile impurities. Accordingly, by improving vacuum conditions, it is possible to reduce the level of interstitial impurities, primarily from oxygen. It was shown in $[15,16]$ that under certain conditions, partial purification of the material from oxygen is observed due to the fact that atomic hydrogen released during the decomposition of titanium and zirconium hydrides actively interacts with the oxygen of the oxide layer on the surface of the powders with the formation of the $\mathrm{H}_{2} \mathrm{O}$ molecule, which then leaves the material and is removed by a vacuum pumping system. And this process takes place the more intensively, the better the vacuum in the chamber.

\subsection{COOLING CONDITIONS}

The influence of the cooling conditions of the samples after sintering in vacuum was investigated in two versions. The first mode is cooling the sample from sintering temperature to room temperature together with the furnace for $20 \mathrm{~h}$. The second mode is the lowering of the sample from the heating zone and rapid cooling to room temperature in $30 \mathrm{~min}$ (No. 3a, 3b). As shown by $\mathrm{XRD/SEM} / \mathrm{EDX}$ studies in both modes, a similar structure is formed.

\subsection{COMPACTING. METHOD OF MIXING THE ORIGINAL COMPONENTS}

In this study, the following methods of mixing the starting components were tested in the manufacture of samples:

a) "drunk barrel" mixer for $60 \ldots 120 \mathrm{~min}$ at a rotational speed of $\sim 30 \ldots 40 \mathrm{rpm}$; b) hand rubbing/mixing in alundum mortar;

c) high-energy grinding/mixing in a ball mill.

The results of SEM/EDX studies showed that manual mixing and mixing in a "drunk barrel" gives an inhomogeneous distribution of components over the sample, which after sintering leads to local heterogeneity in elemental and phase composition. This is especially noticeable when using the starting components of different dispersions. The best result is obtained when using short-term joint mechanical activation of components with the same dispersion. After sintering, such samples showed the composition corresponding to the given one, without local heterogeneities and deviations.

\subsection{METHOD OF COMPACTION/PRESSING. THE EXTENT OF PRESSING}

The obtained mixture of powders was compacted with a different degree of unilaterally pressing: from 3 to $80 \mathrm{t}$ into cylindrical briquette $\varnothing 15 \ldots 30 \mathrm{~mm}$ in diameter and height $6 \ldots 25 \mathrm{~mm}$. The data obtained after the sintering of samples with different degrees of compaction show that the degree of compaction mainly affects the porosity of the final material and does not significantly affect its structural-phase state. In the course of the work, the optimal pressing parameters were empirically selected. Given the high fragility of $\mathrm{TiH}_{2}$ and $\mathrm{ZrH}_{2}$, as well as their low ductility, the pressing of these samples presents a certain technical difficulty:

a) at low load $(1 \ldots 10 \mathrm{t})$, the mixture of the starting powders is not compressed and the sample crumbles;

b) at high pressure $(40 \ldots 80 \mathrm{t})$, re-pressing cracks occur in the sample and the samplecrumbles when pressed out of the mold.

The mode for pressing samples weighing $35 \ldots 50 \mathrm{~g}$ was selected experimentally, the load is optimal $\left(3.3 \ldots 7.2 \mathrm{t} / \mathrm{cm}^{2}\right)$.

Further studies on the synthesis of quasicrystals in the Ti-Zr-Ni system were carried out on samples of the composition $\mathrm{Ti}_{40} \mathrm{Zr}_{40} \mathrm{Ni}_{20} / \mathrm{Ti}_{44} \mathrm{Zr}_{40} \mathrm{Ni}_{16}$. The first is the theoretically calculated optimal composition for the formation of the QC phase, according to the literature [13]. The second corresponds to the composition of quasicrystals obtained by the hydride cycle technology at the Institute of Macrokinetics [10].

Samples No. 3a, 3b were synthesized under equal heat treatment conditions (samples were sintered at the same time) using finely divided initial components and selected mixing/pressing parameters. As can be seen from the data presented, the composition of the samples affected the final structural phase state. The phase ratio and lattice parameters have slightly changed. According to published data, the presence of a certain amount of the Laves phase of L-TiZrNi and $\alpha-(\mathrm{Ti}, \mathrm{Zr})$ is characteristic of QC materials of the Ti-Zr-Ni system. Therefore, subsequent studies were carried out with the same compounds, but aimed at reducing the oxygen content. The use of finely dispersed starting components and mechanical activation grinding in a planetary mill made it possible to lower the sintering temperature with the formation of a triple alloy to $870{ }^{\circ} \mathrm{C}$. However, as can be seen from the above XRD data, sintering does 
not occur at lower temperatures. Samples that were annealed at low temperature and in which there was no interaction between the components were subjected to vacuum refining in an electron beam melting unit in order to reduce the content of interstitial impurities (primarily oxygen).

\subsection{EFFECT OF IMPURITIES}

As it turned out during the research, this is the most important parameter affecting the formation of a QC structure. Regardless of carefully selected optimal parameters of the heat treatment modes using the hydride cycle technology, the presence of interstitial impurities $\left(\mathrm{O}_{2}, \mathrm{~N}_{2}, \mathrm{C}\right)$ adversely affects the formation of quasicrystals. Thus, with oxygen content in the sample exceeding $3000 \mathrm{ppm}(0.3 \mathrm{wt} \%)$, the formation of the QC phase is leveled due to the stabilization of the $(\mathrm{Ti}, \mathrm{Zr})_{2} \mathrm{Ni}$ phase by oxygen and the formation of the Laves phase L-TiZrNi instead of quasicrystals. Given that active metals such as titanium and zirconium, which have a high affinity for oxygen, are used, it is extremely difficult to reduce the concentration of $\mathrm{O}_{2}$ in the samples. Especially considering that the initial raw materials are finely divided powders with a highly developed surface on which a significant amount of gas impurities is adsorbed. This is currently the main problem in obtaining stable quasicrystals in the $\mathrm{Ti}-\mathrm{Zr}-\mathrm{Ni}$ system using the proposed hydride cycle technology. At this point, attention was repeatedly paid to publications on quasicrystals synthesis by other methods. Thus, the use of the fast quenching method allows one to slightly increase the limiting oxygen content in the samples, and high cooling rates suppress the precipitation of the $(\mathrm{Ti}, \mathrm{Zr})_{2} \mathrm{Ni}$ phase and the Laves phase of $\mathrm{L}-\mathrm{TiZrNi}$ forming quasicrystals [5]. It was theoretically proved $[18,19]$ that quasicrystals is a low-temperature stable phase in the $\mathrm{Ti}_{40} \mathrm{Zr}_{40} \mathrm{Ni}_{20}-\mathrm{Ti}_{41.5} \mathrm{Zr}_{41.5} \mathrm{Ni}_{17}$ system, while the Laves phase L-TiZrNi is stable at high temperatures (at $\mathrm{T}>700{ }^{\circ} \mathrm{C}$ ).

To confirm the significant effect of interstitial impurities on the final structure of alloys of the Ti-Zr-Ni system, we studied the effect of refining electron-beam remelting of samples No. $4 \mathrm{a}, 4 \mathrm{~d}$ annealed at temperatures insufficient to obtain a ternary alloy. An important result of this study is that a favorable effect of refining remelting on the structural state of the alloy was established. As can be seen from Table 2, the phase composition of the samples after electron beam melting No. $4 \mathrm{c}, 4 \mathrm{e}$ dramatically differs in the ratio of the phases L-TiZrNi and $(\mathrm{Ti}, \mathrm{Zr})_{2} \mathrm{Ni}$ compared with samples of the same composition after sintering (for example No. 3a, 3b). An increase in the amount of the L-TiZrNi phase is proportional to a decrease in the amount of the $(\mathrm{Ti}, \mathrm{Zr})_{2} \mathrm{Ni}$ phase. This indicates that, during the melting in a vacuum, the oxygen content in the sample decreases, which is responsible for the appearance of the $(\mathrm{Ti}, \mathrm{Zr})_{2} \mathrm{Ni}$ phase in the composition region corresponding to the L-TiZrNi phase (high-temperature phase of the Ti-Zr-Ni system). In addition, it was found that in samples No. 4a, $4 \mathrm{~d}$ annealed at temperatures of 800 and $830^{\circ} \mathrm{C}$, in which dehydrogenation occurred, but the alloy did not form, the self-propagating hightemperature synthesis in the layer-by-layer combustion mode started at the beginning of the EBM. In this case, the sample was heated above the melting point and began to melt. Therefore, a small addition of electron beam power led to the complete melting of the sample. The discovered phenomenon led to additional studies aimed at testing the feasibility of synthesizing samples of the Ti-Zr-Ni system in the SHS mode. In Ti-Ni and $\mathrm{Zr}-\mathrm{Ni}$ binary systems, a solid-phase interaction reaction in the SHS mode is possible due to their negative heats of mixing $\Delta \mathrm{H}_{\mathrm{AB}}^{\mathrm{mix}}$ (Ti-Ni) $=-35 \mathrm{~kJ} / \mathrm{mol}[20]$ and $\Delta \mathrm{H}_{\mathrm{AB}}^{\mathrm{mix}}$ $(\mathrm{Zr}-\mathrm{Ni})=-49 \mathrm{~kJ} / \mathrm{mol}$, respectively. Those, it is quite possible that such processes can occur in the ternary Ti-Zr-Ni system.

Fig. 6 shows the appearance of $\left(\mathrm{TiH}_{2}\right)_{40} \mathrm{Zr}_{40} \mathrm{Ni}_{20}$ samples after pressing and heat treatment in a vacuum under various conditions. The above images clearly show the changes that the samples undergo, depending on the selected modes.

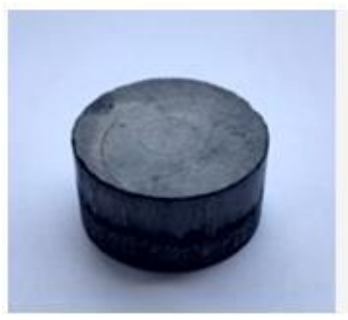

$a$

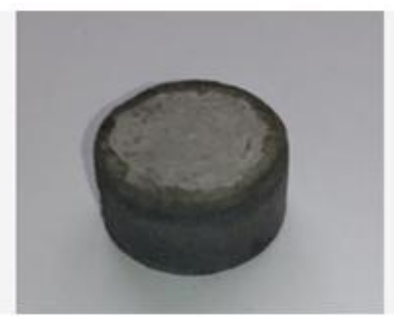

$b$

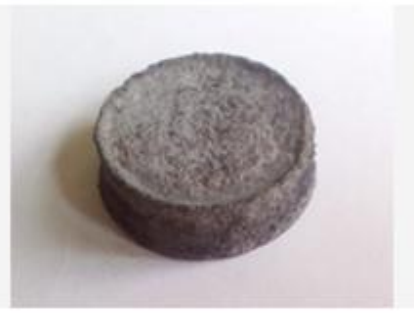

c

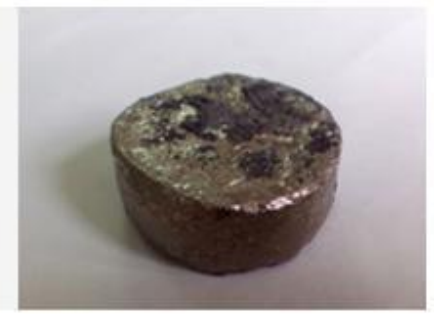

$d$

Fig. 6. Appearance of samples $\left(\mathrm{TiH}_{2}\right)_{40} \mathrm{Zr}_{40} \mathrm{Ni}_{20}$ : $a$ - initial after pressing; $b-\mathrm{No}$. 4a after annealing in vacuum at $T=800^{\circ} \mathrm{C} ; \mathrm{c}-$ No. $4 \mathrm{~b}$ after annealing in vacuum at $T=870^{\circ} \mathrm{C}$ for $2 \mathrm{~h} ; d-$ No. $4 \mathrm{c}$ after annealing in vacuum at $T=800^{\circ} \mathrm{C}+\mathrm{SHS}$ on $\mathrm{EBM}$

According to the Tamman-Hedwal theory of mechanisms of solid-phase interaction, supplemented by Wagner's theory, it follows that activated states significantly accelerate the course of solid-phase reactions. As indicated above, in the process of hydride dissociation, diffusion processes are activated. Due to an increase in the defect of the crystal structure due to phase transformations and volume effects during thermal desorption of hydrogen, as well as active diffusion of hydrogen, the processes of solid-phase interaction are significantly activated. Accordingly, the temperatures of the onset of the interaction of the particles of the starting components with each other can be lower than during fusion by traditional methods. In addition, according to Hedwal, if one substance can undergo a polymorphic transformation, then this transformation is a very favorable moment for the reaction of the interaction of two solids. Or in other 
words, in the case of a polymorphic transformation of one of the components of the mixture at a relatively low temperature, the chemical reaction begins and proceeds intensively at the point of this polymorphic transformation. In the case of the Ti-Zr-Ni system, there are two components with a polymorphic transition in the temperature range $863 \ldots 883^{\circ} \mathrm{C}$ for $\mathrm{Zr}$ and $\mathrm{Ti}$, respectively. As further studies showed, in the synthesis of samples of composition $\left(\mathrm{TiH}_{2}\right)_{41.5} \mathrm{Zr}_{41.5} \mathrm{Ni}_{17}$ (in at.\%, powder $\mathrm{TiH}_{2}, \mathrm{Zr}$, fine PNE-1, without mechanical activation), thermocouples in direct contact with the sample recorded a sharp jump in temperature from 865 up to $954{ }^{\circ} \mathrm{C}, \Delta \mathrm{T}=89^{\circ} \mathrm{C}$. This indicates the occurrence of an exothermic reaction of solid-phase interaction in the "thermal explosion" mode. This was confirmed by visual observation during the heating of samples in a quartz ampoule. A graph of the temperature dependence of the sample during synthesis is shown in Fig. 7.

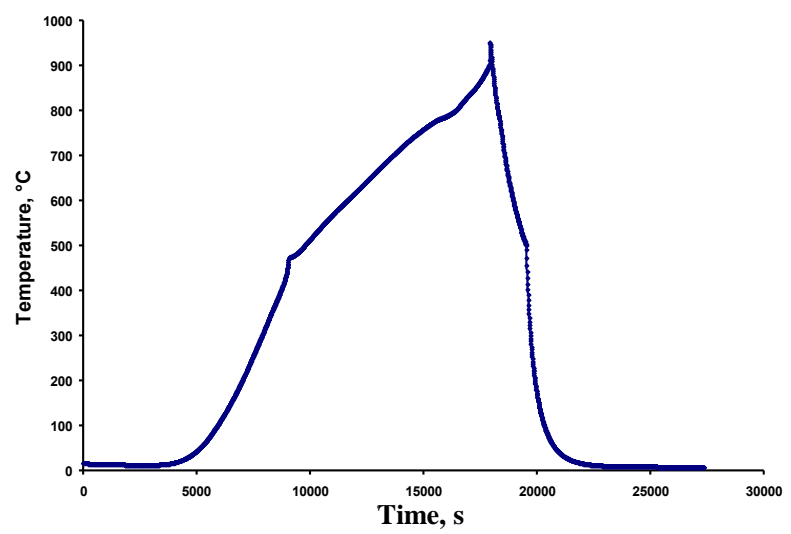

Fig. 7. The temperature change of the pressed sample $\left(\mathrm{TiH}_{2}\right)_{41.5} \mathrm{Zr}_{41,5} \mathrm{Ni}_{17}$ upon heating in vacuum

Thus, it turned out that, in fact, the synthesis of a ternary Ti-Zr-Ni alloy does not occur by the mechanism of slow diffusion solid-phase sintering, but in the process of a short-term exothermic reaction between particles of $\mathrm{Ti}, \mathrm{Zr}$, and $\mathrm{Ni}$, occurring in the thermal explosion mode. It is also possible to synthesize in a layer-by-layer combustion mode during preliminary annealing in the temperature range $800 \ldots 830{ }^{\circ} \mathrm{C}$ to remove hydrogen and subsequent local initiation of SHS. However, for the successful synthesis of a ternary alloy, it is necessary to use finely dispersed starting components with a size of $1 \ldots 10 \mu \mathrm{m}$, since in the case of different dispersion the temperature of initiation of the SHS reaction increases significantly and local heterogeneities in composition arise. The structural phase state of the final material depends on the presence of interstitial impurities, primarily on the oxygen content. Because in this study, the total amount of oxygen in the starting components exceeded 3000 ppm, and samples with a QC structure were not obtained. To form a QC structure using the hydride cycle technique, it is necessary to reduce the oxygen content in the samples. The following options are possible for this:

- use of starting high-purity components (powders of $\mathrm{Ti}, \mathrm{Zr}, \mathrm{Ni}$ );

- hydrogenation of $\mathrm{Ti}$ and $\mathrm{Zr}$ with high-purity hydrogen;

- use of deoxidizing / microalloying Al, Y, Sc.

\section{CONCLUSIONS}

In this work, the main key parameters of the formation of intermetallic compounds of the $\mathrm{Ti}-\mathrm{Zr}-\mathrm{Ni}$ system by the "hydride cycle" method are established. The optimal modes of the technological chain of sample production were selected. The heat treatment parameters are empirically selected and their influence on the structural state of the synthesized alloys is determined. The influence of various factors on the synthesis process and on the final structural phase state of materials has been established. It has been established that the key factors in the formation of ternary compounds of the $\mathrm{Ti}-\mathrm{Zr}-\mathrm{Ni}$ system during hydride dissociation are the dispersion and homogeneity of the initial compacted components.

The causes of the destruction of the QC phase and the formation of substituent phases are determined: the Laves phase of $\mathrm{L}-\mathrm{TiZrNi}$ and the phase $(\mathrm{Ti}, \mathrm{Zr})_{2} \mathrm{Ni}$ arising from the high oxygen content. Regardless of the initial composition, all samples of $\mathrm{Ti}_{40.5} \mathrm{Zr}_{31.9} \mathrm{Ni}_{27.6}$, $\mathrm{Ti}_{41.5} \mathrm{Zr}_{41.5} \mathrm{Ni}_{17}, \mathrm{Ti}_{40} \mathrm{Zr}_{40} \mathrm{Ni}_{20}, \mathrm{Ti}_{44} \mathrm{Zr}_{40} \mathrm{Ni}_{16}$ contained the dominant phase $(\mathrm{Ti}, \mathrm{Zr})_{2} \mathrm{Ni}$ and a smaller amount of $\mathrm{L}$ TiZrNi and (Ti, Zr)- $\alpha$. Mechanisms for reducing the oxygen content are proposed and the efficiency of using refining remelts in vacuum to reduce interstitial impurities is shown.

It was found that during the "hydride cycle" the synthesis of ternary alloys in the Ti-Zr-Ni system occurs during a short-term exothermic reaction related to SHS and proceeding in the "thermal explosion" mode. SHS begins in the temperature region corresponding to the $\alpha \leftrightarrow \beta$ polymorphic transformation of titanium and zirconium.

\section{FUNDING}

This work was supported by non-profit corporation Quantum Gravity Research, CA, USA.

\section{REFERENCES}

1. R.M. Stroud, A.M. Viano, E.H. Majzoub, P.C. Gibbons, K.F. Kelton. Ti-Zr-Ni quasicrystals: structure and hydrogen storage // Materials Research Society. Symp. Proc. 1996, N 400, p. 255-260.

2. R.M. Stroud, K.F. Kelton, S.T. Misture. Hightemperature $\mathrm{X}$-ray and calorimetric studies of phase transformations in quasicrystalline Ti-Zr-Ni alloys // $J$. Mater. Res. 1997, N 12(2), p. 434-438.

3. I. Zavaliy, G. Wojcik, G. Mlynarek, I. Saldan, V. Yartys, M. Kopczyk. Phase-structural characteristics of (Ti1-xZrx)4Ni2O0.3 alloys and their hydrogen gas and electrochemical absorption-desorption properties // Journal of Alloys and Compounds. 2001, N 314, p. 124131.

4. O.Ye. Dmytrenko, I.V. Kolodiy. Influence of the hydrogen saturation temperature on the structure of melt-spun $\mathrm{Ti}_{30} \mathrm{Zr}_{45} \mathrm{Ni}_{25}$ alloys // Problems of Atomic Science and Technology. Series "Vakuum, Pure materials, Superconductors” (22). 2018, N 1(113), p. $162-168$.

5. V.M. Azhazha, A.M. Bovda, S.D. Lavrinenko, L.V. Onishchenko, S.V. Malykhin, A.T. Pugachev, M.V. Reshetnyak, A.N. Stetsenko, B.A. Savitsky. Synthesis and stability of Ti-Zr-Ni quasicrystals // 
Problems of Atomic Science and Technology. Series "Vacuum, Pure materials, Superconductors". 2007, N 4, p. 82-87.

6. S.K. Dolukhanyan, A.G. Aleksanyan, V.Sh. Shekhtman, A.A. Mantashyan, D.G. Mailyan, O.P. TerGalstyan. A new method for producing alloys based on transition metals // Chemical Journal of Armenia. 2007, N 60(4), p. 545-569.

7. S.K. Dolukhanyan, A.G. Aleksanyan, O.P. TerGalstyan, V.Sh. Shekhtman, M.K. Sakharov, G.E. Abrosimova. Specifics of the formation of alloys and their hydrides in the Ti-Zr-H system // Russ. J. Phys. Chem. B. 2007, N 2(6), p. 563-569.

8. A.G. Aleksanyan, S.K. Dolukhanyan, A.A. Mantashyan, D.G. Mailyan, O.P. Ter-Galstyan, V.Sh. Shekhtman. A new technique for producing alloys based on transition metals // Carbon nanomaterials in clean energy hydrogen systems. Springer, 2008, p. 783-794.

9. S.K. Dolukhanyan, A.G. Aleksanyan, V.Sh. Shekhtman, H.G. Hakobyan, D.G. Mayilyan, N.N. Aghadjanyan, K.A. Abrahamyan, N.L. Mnatsakanyan, O.P. Ter-Galstyan. Synthesis of transition metal hydrides and a new process for production of refractory metal alloys // International Journal of SelfPropagating High-Temperature Synthesis. 2010, N 19(2), p. 85-93.

10. V.Sh. Shekhtman, H.G. Hakobyan, A.G. Aleksanyan, S.K. Dolukhanyan, O.P. Ter-Galstyan, M.K. Sakharov. The formation of quasicrystals and their hydrides in Ti-Zr-Ni system // International Journal of hydrogen energy. 2011, N 36, p. 1206-1208.

11. D.G. Savvakin, M.M. Gumenyak. Synthesis of alloys based on the binary $\mathrm{Zr}$-Ti system using dispersed zirconium hydride // Metallophysics and the Latest Technology. 2013, N 35(3), p. 349-358.

12. O.M. Ivasishin, V.N. Voyevodin, P.E. Markovsky, M.M. Pylypenko, D.G. Savvakin, S.D. Lav- rinenko, O.P. Karasevska. The microstructure and characteristics of the $\mathrm{Zr}-1 \% \mathrm{Nb}$ alloy synthesized from heterogeneous powder mixtures // Problems of Atomic Science and Technology. 2015, N 2(96), p. 65-72.

13. J.B. Qiang, Y.M. Wang, D.H. Wang, M. Kramer, P. Thiel, C. Dong. Quasicrystals in the TiZr-Ni alloy system // Journal of Non-crystalline Solids. 2004, N 334\&335, p. 223-227.

14. O.M. Ivasishin, A.B. Bondarchuk, M.M. Gumenyak, D.G. Savvakin. Surface phenomenon upon heating of titanium hydride powder // Physics and Chemistry of Solid State. 2011, N 12(4), p. 900-907.

15. O.M. Ivasishin, D.G. Savvakin, M.M. Gumenyak. Dehydrogenation of titanium hydride powder and its role in sintering activation // Metallophysics and Latest Technologies. 2011, v. 33, N 7, p. 899-917.

16. D.G. Savvakin, N.M. Humenyak, M.V. Matviychuk, O.G. Molyar. The role of hydrogen in sintering of titanium powders // Physicochemical Mechanics of Materials. 2011, N 5, p. 72-81.

17. O.M. Ivasishin, D.G. Savvakin. Synthesis of alloys based on zirconium and titanium using their hydrides // Physicochemical Mechanics of Materials. 2015, N 4, p. 27-35.

18. R.G. Hennig, A.E. Carlsson, K.F. Kelton, C.L. Henley. Ab initio Ti-Zr-Ni phase diagram predicts stability of icosahedral TiZrNi quasicrystals // Physical Review B. 2005, N 71, p. 144103-1-10.

19. R.G. Hennig, A.E. Carlsson, K.F. Kelton, C.L. Henley. Icosahedral Ti-Zr-Ni: A groundstate quasicrystal? eprint arXiv:cond-mat/0205202 [condmat.mtrl-sci]. May 2002.

20. É. Fazakas, L.K. Varga. Effect of valence electron concentration on the glass-forming ability in Al-based alloys // International Journal of Engineering and Applied Sciences (IJEAS). 2015, N 2(11), p. 115121.

Article received 24.11.2021

\title{
СИНТЕЗ Ti-Zr-Ni-CПЛАВОВ МЕТОДОМ «ГИДРИДНОГО ЦИКЛА»
}

\author{
А.Е. Дмитренко, И.В. Колодий, Т.Б. Янко, В.М. Борисенко, К. Ирвин, Р.Л. Василенко
}

Проведены комплексные исследования технических параметров и условий синтеза тройных сплавов в системе Ti-Zr-Ni методом «гидридного цикла». Определено влияние на процесс синтеза таких параметров, как: температура и время отжига, скорость нагрева, условия охлаждения, состав материала, дисперсность, содержание водорода в используемых гидридах, наличие примесей, способы смешивания и прессования, а также степень прессования исходных компонентов. Синтезированы и исследованы сплавы следующих составов: $\mathrm{Ti}_{40,5} \mathrm{Zr}_{31,9} \mathrm{Ni}_{27,6}, \mathrm{Ti}_{41,5} \mathrm{Zr}_{41,5} \mathrm{Ni}_{17}, \mathrm{Ti}_{40} \mathrm{Zr}_{40} \mathrm{Ni}_{20}, \mathrm{Ti}_{44} \mathrm{Zr}_{40} \mathrm{Ni}_{16}$. Определены оптимальные технологические параметры и условия синтеза тройных сплавов. Установлено, что ключевыми факторами в процессе образования соединений при диссоциации гидридов являются дисперсность и однородность исходных спрессованных компонентов. Установлено, что синтез тройных сплавов в системе Ti-Zr-Ni происходит в ходе кратковременной экзотермической реакции в режиме «теплового взрыва», которая начинается в области температур, соответствующей полиморфному превращению $\alpha \leftrightarrow \beta$ циркония и титана.

\section{СИНТЕЗ Ti-Zr-Ni-CПЛАВІВ МЕТОДОМ «ГІДРИДНОГО ЦИКЛУ»}

\section{О.С. Дмитренко, І.В. Колодій, Т.Б. Янко, В.М. Борисенко, К. Ірвін, Р.Л. Василенко}

Проведено комплексне дослідження технічних параметрів та умов синтезу потрійних сплавів у системі Ti-Zr-Ni методом «гідридного циклу». Було визначено вплив на процес синтезу таких параметрів, як: 
температура і час відпалу; швидкість нагрівання; умови охолодження; склад матеріалу; дисперсність; вміст водню в гідридах, що використовуються; наявність домішок; способи змішування і пресування, а також ступінь пресування вихідних компонентів. Синтезовано та досліджено сплави наступних складів: $\mathrm{Ti}_{40,5} \mathrm{Zr}_{31,9} \mathrm{Ni}_{27,6}, \mathrm{Ti}_{41,5} \mathrm{Zr}_{41,5} \mathrm{Ni}_{17}, \mathrm{Ti}_{40} \mathrm{Zr}_{40} \mathrm{Ni}_{20}, \mathrm{Ti}_{44} \mathrm{Zr}_{40} \mathrm{Ni}_{16}$. Визначено оптимальні технологічні параметри та умови синтезу потрійних сплавів. Встановлено, що ключовими факторами в процесі утворення сполук при дисоціації гідридів є дисперсність та однорідність вихідних спресованих компонентів. Встановлено, що синтез потрійних сплавів у системі Ti-Zr-Ni відбувається в ході короткочасної екзотермічної реакції в режимі «теплового вибуху», яка починається в області температур, що відповідає поліморфному перетворенню $\alpha \leftrightarrow \beta$ цирконію та титану. 